Cecilia Toseli

Regina Maria Manoel

\title{
A comunidade do Povo da Rua na Baixada do Glicério
}

\author{
The Community of Homeless People in \\ The Baixada do Glicério
}

\begin{abstract}
Resumo
Este artigo apresenta a história da comunidade do Povo da Rua na Baixada do Glicério, na cidade de São Paulo/Brasil, ao longo de seus 40 anos. O caminho de formação de comunidade de fé e vida com pessoas que viviam (e ainda vivem) nas ruas da cidade de São Paulo e o processo de conquista de direitos e elaboração de políticas públicas tiveram (e ainda têm) como objetivo reconhecer o protagonismo/profetismo político e eclesial do povo da rua na transformação do modo de lidar com estruturas opressoras.
\end{abstract}

Palavras-chave: Povo da rua, Comunidade eclesial, Direitos, Políticas públicas, Protagonismo/profetismo.

\begin{abstract}
This article presents the history of the homeless community in Baixada do Glicério, in the city of São Paulo / Brazil, over its 40 years. The journey of forming a community of faith and life with people who lived (and still live) on the streets of the city of São Paulo and the process of conquering rights and developing public policies aimed (and still aim) to recognize the political and ecclesial protagonism/prophetism of the people of the street in transforming the manner of dealing with oppressive structures.
\end{abstract}

Key- Words: Homeless, Ecclesial community, Rights, Public policies, Protagonism/prophetism.

\section{O começo}

A comunidade do povo da rua na Baixada do Glicério, região central da cidade de São Paulo/Brasil, tem uma longa história...

Regina faz parte do grupo ${ }^{1}$ que começou a reunir as pessoas que viviam na rua no final da década de 1970, no centro de São Paulo. A intenção

${ }^{1}$ Fraternidade Oblatas de São Bento, fundada em São Paulo por D. Inácio Lezama, monge beneditino-olivetano, uruguaio, em 1953. E-mail: regina.mar@globo.com 
era mobilizá-las em comunidades de fé e vida e articular a organização para a conquista de direitos e a elaboração de políticas públicas a partir dos viadutos e ruas da cidade. Cecilia ${ }^{2}$ ingressou na comunidade do povo da rua no final dos anos noventa, quando veio morar no centro da cidade.

A comunidade do povo da rua nasceu de um grupo de mulheres, monjas beneditinas, que, trabalhando na Organização de Auxílio Fraterno $(\mathrm{OAF})^{3}$, inquietas e reflexivas sobre os desafios da cidade, decidiram fechar a instituição e iniciar um novo caminho no qual pudessem se aproximar da maneira de pensar e viver das pessoas que viviam na rua, o que significou formar comunidade com o povo da rua.

O contexto social do país era de intensa migração interna para as grandes cidades - o período chamado de "êxodo rural", com o esvaziamento do campo e o inchamento do meio urbano. Porém, com a crise da construção civil na década de 80 , muita gente que aí trabalhava, viu-se desempregada. Sendo a maioria dessas pessoas homens sozinhos, provenientes da região Nordeste do Brasil, e se sentindo "envergonhados" diante da impossibilidade de se sustentar, enviar algum dinheiro para suas famílias que lá ficaram, ou mesmo retornarem para seus lugares de origem, muitos permaneceram na cidade e foram viver na rua.

Do ponto de vista eclesial, as pessoas que viviam na rua não eram aceitas nas paróquias, provavelmente por suas roupas, pelas condições de higiene de seus corpos ou por transtornos mentais. Ao mesmo tempo, esse foi o período do florescimento das Comunidades Eclesiais de Base, que, em São Paulo, cresceram sobretudo na periferia da cidade, e do aprofundamento da Teologia da Libertação, que inspirou um outro jeito de ser igreja.

\section{Da instituição para a rua}

As monjas participavam da OAF, que era uma entidade social que trabalhava no centro da cidade de São Paulo, desde 1953, com diversos grupos oprimidos: "pobres", "abandonados", "marginalizados", "excluídos", "descartáveis", "invisíveis" - assim foram rotulados ao longo dos anos até os nossos dias. A instituição era altamente reconhecida pela sociedade paulistana à sua época. No entanto, chegara a hora da mudança. Era por volta de 1976.... Nasciam os movimentos populares, fortalecia-se o processo de anistia dos presos políticos pelo golpe de 1964, que instaurou a ditadura militar no Brasil, cresciam os sindicatos, partidos políticos etc.

Em atitude permanente de profunda reflexão e provocada pelas Assembleias Episcopais Latino-Americanas de Medellín/Colômbia de 1968 e,

\footnotetext{
${ }^{2}$ Bolsista da CAPES no Programa de Pós-Graduação em Ciências da Religião da Universidade Metodista de São Paulo. E-mail: cecilia.toseli@gmail.com. Este trabalho, contudo, está ligado à trajetória pessoal e não à vida acadêmica da autora.

${ }^{3}$ Entidade filantrópica de atendimento social, fundada pela Fraternidade Oblatas de São Bento. A mudança da OAF se deu a partir da inspiração de Griselda Castelvechi, conhecida como "Nenuca".
} 
sobretudo, de Puebla/México de 1979, a equipe da OAF decidiu-se pelo fechamento da instituição ${ }^{4}$, no auge de sua atuação, para iniciar uma nova etapa. Como nos disse D. Paulo Evaristo Arns, Arcebispo de São Paulo, naquela ocasião: "Coloquem Puebla no centro da cidade de São Paulo", porque as congregações religiosas iam para a periferia da cidade, e nós estávamos na "periferia" do centro.

Dentre crianças, adolescentes, homens, mulheres, desempregados, egressos do sistema prisional, pessoas que tentaram o suicídio, portadores de sofrimento mental... dentre todos esses, as pessoas que obtinham menos atenção (praticamente nenhuma) da sociedade civil e do poder público eram as que viviam na rua. A decisão de fechar a instituição se deu juntamente com a escolha de trabalhar exclusivamente com a população adulta que vivia nas ruas do centro da cidade de São Paulo (àquela época, quase não havia crianças na rua). E o fechamento da instituição era imprescindível, segundo a avaliação dos membros da OAF, porque as pessoas da rua também viviam um círculo vicioso: por menor que fosse, a burocracia, a formalidade e a hierarquia institucional reforçavam a condição das pessoas que viviam na rua como objeto da ação social: de um lado, o "assistido" e, do outro, a/o assistente social. Não havia interação entre eles. Era um modelo que impedia que conseguissem sair da rua, e tivessem um lugar social. Era necessário que os "pobres" tivessem voz, proferissem a sua palavra de sentido como sujeitos, protagonistas de suas histórias. E, na instituição, isso nunca aconteceria. O rompimento com a instituição era um caminho para que as pessoas que viviam na rua tivessem seu lugar de participação na sociedade.

A OAF tinha mais de 50 funcionários. Todos tiveram a oportunidade de participar de uma avaliação institucional e, depois da decisão do fechamento, puderam optar por ficar no trabalho ou fazer seu acerto de contas. As exigências para fazer parte da equipe de base eram querer trabalhar fora de parâmetros institucionais e morar no centro da cidade. Este critério estava ligado ao fato de que todos os nossos lugares de trabalho foram fechados, mas sabíamos onde as pessoas estavam: elas estavam no centro da cidade. Então, nossas casas se tornariam o ponto de referência.

Neste novo caminho, decidimos começar pela busca de uma nova expressão da fé, pois, afinal, toda a ação social da OAF nascera da intuição de fé daquele grupo de beneditinas e leigos/as. Pois, além do lugar social, era necessário também um lugar onde as pessoas que viviam na rua pudessem viver a sua espiritualidade e formar comunidade eclesial, visto que eram impedidas de entrar nas igrejas, ou eram tratadas como objeto de caridade.

\footnotetext{
${ }^{4}$ A OAF fechou todos os seus setores de trabalho (casa de meninos, albergues, oficinas de trabalho, abrigos etc), mantendo apenas um escritório administrativo. Durante todo esse tempo, ficou apenas como mantenedora da equipe de base. Com a organização dos/as catadores/as e o crescimento da ação com a população em situação de rua, ela emergiu como entidade parceira e assim permanece atualmente.
} 
Algumas "palavras-chave" 5 , como comunidade, fraternidade, união..., nos orientavam a criar experiências e relações que nos fizessem ser irmãol irmã - este era o sentido da comunidade que nasceria com o povo da rua. Quando dizíamos que queríamos formar comunidade com as pessoas que viviam na rua, isto significava que queríamos formar comunidade de fé e vida, conviver no dia-a-dia, entrelaçar nossas histórias... a ponto de algumas pessoas da rua virem morar conosco por pequenos períodos. Compartilhávamos cem por cento do nosso tempo - não se tratava mais de ações assistenciais, isoladas, em determinados dias da semana ou por algumas horas, nem de ter uma casa de prestação de serviços, ou de "fazer pastoral" de final de semana. Formar comunidade com as pessoas que viviam na rua significava, na dimensão eclesial, reconhecer o protagonismo de sua fé e o seu jeito de ser igreja, que anunciava, profeticamente, a transformação de estruturas injustas.... dentro e fora da/s igreja/s.

E, para isso, decidimos que nossa preparação seria ir para a rua, passar um tempo na rua: dormir na rua, debaixo de viadutos e marquises, em albergues, estações ferroviárias, vender sangue nos "bancos de sangue" da cidade, catar materiais recicláveis junto com as pessoas, fazer e vender artesanato nas praças, ir às delegacias pedir passagem de trem para viajar para outras cidades, vender cafezinho na feira ou à porta das igrejas. Sabíamos que isso não era um tipo de "faz de conta que somos da rua". Tratava-se, ao contrário, de uma maneira de nos aproximar e experimentar por dentro o que as pessoas que viviam na rua experimentavam: ser humilhado, ter medo, ser discriminado, sofrer com o preconceito, o pouco-caso e a indiferença. Queríamos participar do dia-a-dia das pessoas que viviam na rua porque nos perguntávamos se essa rua tinha saída. E, sim, "Essa rua tem saída"

Uma referência importante no processo de mudança da OAF foi a Ronda Noturna. Desde os anos 60, a equipe da OAF saía do escritório e dos equipamentos da Assistência Social, juntamente com outras pessoas que tomavam conhecimento dessa ação, para levar, à noite, chá, sanduíche e cobertor para as pessoas que dormiam na rua, e para conversar com elas. Aproveitando os contatos feitos à noite, começamos a realizar encontros durante o dia, debaixo de viadutos e em praças, fazer passeios e retiros fora da cidade, para aprofundar a relação com as pessoas que viviam na rua.

Assim, celebramos, em 1978, pela primeira vez com o povo da rua, a Sexta-Feira Santa, nos porões da igreja de Santa Ifigênia. Como as pessoas da rua não tinham lugar fixo, nós precisávamos criar um espaço permanente aonde elas pudessem ir com regularidade. Em 1979, tivemos a oportunidade de nos reunir em uma casa velha nos fundos do Mosteiro de São

\footnotetext{
${ }^{5} \mathrm{O}$ uso de palavras-chave seguia a inspiração do metódo do educador brasileiro Paulo Freire. ${ }^{6}$ Tema da celebração dos 50 anos da Organização de Auxílio Fraterno, realizada na Casa de Oração do Povo da Rua.
} 
Bento. Ali, nascia, então, a Casa de Oração do Povo da Rua, ecoando a profecia de Isaías (cf. Is 56,7). Tudo isso antes de fechar a OAF.

\section{A Casa de Oração do Povo da Rua}

Curiosamente, mas sintomaticamente também, no começo, e várias vezes ao longo de sua história, a Casa de Oração não teve um espaço fixo, mas nem por isso deixávamos de nos reunir e celebrar. Na rua, no porão da igreja de Santa Ifigênia, nos fundos do Mosteiro de São Bento, nos fundos da igreja de S. Francisco... Sempre que queriam o espaço, pediam que nos retirássemos: Tem piedade, ó Senhor, tem piedade... quando o povo é enxotado da cidade, com indiferença e tão grande humilhação... assim cantávamos na Semana Santa. Cantávamos, dançávamos, fazíamos brincadeiras, tínhamos grupos de leitura bíblica, celebrávamos a liturgia do domingo e fazíamos um lanche a partir do que as próprias pessoas da rua podiam disponibilizar. A Casa de Oração é de origem cristã, católica, com acolhimento ecumênico e interreligioso. Nunca foi um espaço eclesiástico, não nasceu em uma paróquia, nem da ação de uma pastoral - ao contrário, ela provocou a criação da Pastoral da Rua ${ }^{7}$ - mas sempre foi um lugar de encontro e expressão autêntica da fé, e de inspiração para buscar mudanças nas estruturas sociais.

Quando D. Paulo Evaristo Arns, que foi um grande apoiador e celebrava conosco debaixo dos viadutos, recebeu um prêmio dos budistas do Japão, houve a disponibilidade de um recurso financeiro. Ele nos perguntou o que queríamos que fizéssemos com o dinheiro (Construir um albergue, um restaurante popular?). Pedimos: uma casa de oração para o povo da rua. A casa foi construída no bairro da Luz e inaugurada em 1997, onde permanece até hoje.

Havia diversas tarefas na casa, sempre realizadas com equipes compostas por pessoas da rua e outras pessoas que estavam conosco nesse caminho: recepção, crachá, animação, canto, decoração, celebração, estudo bíblico, lanche, limpeza.

Os objetos e utensílios na Casa de Oração, no centro comunitário ou debaixo do viaduto eram reaproveitados do descarte feito na rua. Na verdade, essa foi uma prática desde o começo e, mais tarde, deu origem à Casa Cor da Rua, uma casa onde criamos, mais do que um espaço de artesanato, uma oficina de arte e reciclagem, a "A Arte que Vem da Rua", que, inclusive, foi premiada pela renomada revista Casa Claudia, em 2005.

Cantoria, teatro, composição de cantos e confecção de instrumentos musicais e de objetos de decoração para os espaços onde nos encontrávamos, troca de experiências com comunidades eclesiais de base que vinham da periferia de São Paulo passar o dia conosco, passeios para a praia e para o campo, reencontro com familiares, sepulta-

${ }^{7}$ A Pastoral Nacional do Povo da Rua foi reconhecida pela Conferência Nacional dos Bispos do Brasil (CNBB) em 2001 e hoje é um organismo da CNBB e faz parte das pastorais sociais. 
mentos... estreitavam-se nossos laços. Não havia uma catequese formal ou doutrinária. A catequese era fazer junto, ser irmão, irmã. Não se tratava de rezar por, mas rezar com o povo da rua. Celebrávamos as festas do Natal e da Páscoa, e as festas juninas de São João, Santo Antônio, São Pedro e São Paulo.

O povo da rua exercia todos os ministérios nas liturgias que fazíamos na rua, debaixo do viaduto, no centro comunitário ou na Casa de Oração: faziam a recordação da vida, cantavam e tocavam os Salmos, liam a Bíblia, abençoavam os alimentos, visitavam companheiros/as nos mocós ${ }^{8}$ e nos hospitais. Aprendíamos na vida e celebrávamos a vida e a morte, cotidianamente. Não saímos dali para ir à missa em outro lugar, nem havia a presença de ministros ordenados. Acreditávamos na verdade do que fazíamos, ou não fazia sentido celebrar.

No dia 25 de julho de 2019, Vera completou 70 anos de vida! Foi uma grande festa! Vera é uma companheira que chegou à comunidade em 1979, sozinha. Teve uma vida muito sofrida antes de ir viver na rua, e ali chegando, como mulher, enfrentou situações inimagináveis. Ao longo de todos esses anos, Vera manteve-se uma mulher íntegra e respeitada por todos. Criou três filhos e os fez crescer amigos um do outro. Tem três netos. Todos vivem próximos, e ela mora em um apartamento adquirido através de um programa da prefeitura.

Em um de seus depoimentos sobre a comunidade, assim Vera se expressou:

Na comunidade, um conhece o outro, fica mais amigo, um ajuda o outro. Eu gosto da convizência entre os irmãos. A comunidade me deu a mão e eu peguei... e saí da rua. $\mathrm{Na}$ rua, o sofrimento era muito grande. Hoje, a comunidade me ajuda a enfrentar as dificuldades e eu ajudo a comunidade a crescer ${ }^{9}$.

Vera representa os 40 anos da história da comunidade do povo da rua do Glicério. Casais se formaram, nasceram crianças, jovens se encaminharam, muita gente morreu. Nunca foi objetivo preparar ninguém para "receber os sacramentos". Porém, dentro de um processo natural e a pedido das próprias pessoas, certas etapas da vida foram celebradas, na comunidade, com gestos sacramentais: batismo, crisma, exéquias. A partilha do pão, nós a fazíamos sempre. Para esses momentos, a preparação era feita com toda a comunidade e, depois, havia o tempo mistagógico, no qual aprofundávamos a experiência vivenciada por todos. A avaliação durante o processo preparatório era feita mediante o testemunho da comunidade quanto ao amadurecimento do/a candidato/a na vida comunitária.

\footnotetext{
${ }^{8}$ Linguagem popular para moradia improvisada, escondida, precária.

${ }^{9}$ Depoimento concedido à Cartilha Pastoral do Povo da Rua: Vida e Missão, da Equipe de Coordenação da Pastoral do Povo da Rua - Setor das Pastorais Sociais/CNBB. São Paulo: Loyola, 2003, p.79.
} 
Com o tempo, a Casa de Oração tornou-se, informalmente, a referência da Pastoral da Rua e um centro aglutinador de diversas ações político-sociais não só do povo da rua e dos/as catadores/as, como também de iniciativas de outras pastorais sociais, grupos e movimentos afins.

Diante da ameaça de mudança no cenário eclesial, e dada a peculiaridade da espiritualidade do povo da rua e da metodologia de ação da comunidade, D. Paulo criou o Vicariato Episcopal do Povo da Rua em 1997.

E mais uma vez, em 2012, o grupo de origem que iniciou o caminho com o povo da rua deixou a Casa de Oração no bairro da Luz e retornou para a Baixada do Glicério, onde se reúne atualmente, no mesmo lugar onde tudo começou.

\section{Na rua, a sopa comunitária}

Além da Casa de Oração, uma das primeiras iniciativas após o fechamento da OAF no final da década de 1970 foi reconhecer o entorno de onde morávamos, tanto em relação à rua, quanto em relação às instituições que ali funcionavam. Assim, começamos, por exemplo, no Glicério ${ }^{10}$, a catar frutas no final da feira ${ }^{11}$ de quarta-feira, porque as pessoas da rua iam à feira buscar alimento. E as sobras coletadas, eles levavam para seus mocós para fazer a comida.

Então, começamos a fazer com eles uma sopa debaixo do viaduto: recolhíamos as sobras da feira, o fogo era aceso com os pedaços de madeira dos caixotes de frutas, a água era trazida de um posto de gasolina... levávamos somente o sal, e repartíamos entre todos os que chegavam na hora que estava pronta - era a "sopa comunitária", como chamávamos.

A sopa, por volta de 1980, foi muito importante no processo de consolidação da comunidade e na organização das ações junto à sociedade e ao poder público. Ocorreu, infalivelmente, em todas as quartas-feiras durante 14 anos: inicialmente, era apenas uma lata de 9 litros para 10 a 15 pessoas; no final, eram 10 tambores de 50 litros que alimentavam cerca de 600 pessoas, no fogão à lenha, com madeira coletada na feira. A Baixada do Glicério era uma região extremamente violenta e temida por todos na cidade, mas, na sopa, o ambiente era de paz e comunhão. Eles mesmos cuidavam de lidar com os conflitos que, por vezes, aconteciam.

A sopa crescia.... então começamos a organizar equipes na comunidade que se preparavam para a sopa de quarta-feira debaixo do viaduto do Glicério, para o encontro na Casa de Oração aos domingos e para as atividades nos demais dias da semana no centro comunitário. Sim, junta-

\footnotetext{
${ }^{10}$ Além do Glicério, a sopa era feita por nós em outros lugares da cidade, e havíamos criado também outros centros comunitários, por exemplo, no Parque D. Pedro e no Bairro da Luz, sempre na região central da cidade de São Paulo, onde as pessoas que viviam na rua encontravam mais recursos para a sobrevivência.

${ }^{11}$ As feiras se realizam nas ruas da cidade, em diferentes localidades e dias da semana, onde são vendidos alimentos frescos: legumes, frutas, peixe, frango, carne etc.
} 
mente com a organização da sopa, alugamos uma casa próxima ao viaduto do Glicério onde passou a funcionar um local - o centro comunitário - onde as pessoas podiam tomar banho, ter cuidados com a saúde, lavar roupa, costurar, celebrar os aniversários etc.

No centro comunitário, ao final da sopa, sempre fazíamos avaliação e, em seguida, treinamento (em forma de teatro ou dramatização) de como nos relacionar com os feirantes e com as pessoas da rua que vinham só para comer. Dizíamos que havíamos escolhido realizar aquela tarefa - era o serviço da comunidade, então tínhamos que "conquistar" quem vinha para a sopa, e não simplesmente "jogar na cara"12 que vinham só para comer.

Houve um período de tanta violência na rua que estabelecemos um acordo: "se houvesse briga, não se podia tirar o sangue do/a irmão/ã". A união, a justiça, a solidariedade eram temas permanentes nos grupos de conversa... Nessa época, a violência generalizada chegou a tal ponto no Brasil que, em 1983, a Conferência Nacional dos Bispos do Brasil inseriu como desafio na Campanha da Fraternidade ${ }^{13}$ o tema "Fraternidade e Violência", com o lema "Fraternidade sim, violência não". Esse foi um tema caro à comunidade. Afinal, como dissemos, o sentido da comunidade da rua era ser irmão/ã. Assim, nas ocasições de brigas e conflitos, combinamos que, para participar da celebração ou de qualquer outra atividade, era necessário, sempre, primeiro, se reconciliar com o irmão, a irmã.

E, nos grupos de conversa da comunidade, as pessoas que viviam na rua começavam a se dar conta de suas histórias. Inicialmente, havia uma leitura muito arraigada de que "Estou na rua porque Deus quer, porque é o destino". Porém, no convívio e na escuta do outro, vão percebendo que há um sistema injusto por trás de suas histórias e trajetórias pessoais, e começam a se reconhecer reciprocamente. Foi então que as pessoas passaram a se ver, na comunidade, como povo da rua, em afinidade com o povo de Deus. O tema do êxodo bíblico de Israel e de Jesus sempre foi muito significativo para o povo da rua. Gostávamos de cantar: O povo de Deus no deserto andava, mas à sua frente alguém caminhava... O povo de Deus era rico de nada. Só tinha esperança e o pó da estrada. Também sou teu povo, Senhor, e estou nessa estrada... ${ }^{14}$

\section{A Missão da Rua}

No processo de tomada de consciência nas rodas de conversa da comunidade sobre as causas externas que levaram à condição de viver na rua, começamos a nos organizar em torno de outra data: 7 de setembro, dia da

\footnotetext{
12 “Jogar na cara" é uma expressão com força de acusação, cobrança e constrangimento.

${ }^{13}$ É uma campanha realizada anualmente pela Conferência Nacional dos Bispos do Brasil no período da Quaresma, a fim de despertar a solidariedade em relação a um problema concreto da realidade brasileira. Teve origem em iniciativas realizadas pela Cáritas Brasileira nos anos de 1961/62, no estado do Rio Grande do Norte.

14 "O Povo de Deus", composição de Nelly da Silva Barros, conforme acesso no dia 22/12/2019 no Portal Luteranos.
} 
independência (formal) do Brasil ${ }^{15}$. Na verdade, havia um "vazio" no calendário de atividades da comunidade entre a Páscoa, o Natal e Festas Juninas, ou seja, entre os meses de julho e dezembro. Assim, tivemos a idéia de fazer um grande encontro de três dias, que seria a chamada "Missão da Comunidade dos Sofredores da Rua" (como se auto identificavam, ressoando novamente a profecia de Isaías). A primeira foi em 1979, e continuou por 14 anos consecutivos. Mas, somente em 1982, tomamos coragem para fazer na Missão a primeira caminhada na cidade de São Paulo, com faixas e cartazes denunciando a situação de vida na rua e anunciando entre os "sofredores" da rua que era possível viver como irmãos e irmãs. E a experiência já consolidada de fazer a sopa comunitária era o grande testemunho de que era possível fazer junto, de que, unidos/as, a gente conseguia se organizar e transformar a vida! O lema da primeira Missão, e que se mantém até hoje entre nós, foi "Somos um povo que quer viver!". E houve outros, por exemplo: "Sem trabalho, casa e pão, não há libertação!", "Entre a vida e a morte, a vida é mais forte!”, “Entra na roda da rua! Vem, que a festa é tua!", “Estamos na miséria, queremos justiça séria". Um dos cantos compostos por nós dizia:

Fazer justiça séria pra acabar com a miséria do povo que é sofredor... (bis)

- Boia fria na fazenda, fui expulso do meu chão.

Mas a vida é muito forte, eu não quero a morte, não.

Eu só quero a igualdade no meio desta cidade, para poder ganhar meu pão!

- Eu trabalho há muito tempo e não tive condição.

Eu cheguei nesta cidade, saudade no coração.

Peço a Deus que me ajude, eu já fiz tudo que pude, e não tive chance, não!

As caminhadas na cidade deram visibilidade às pessoas que viviam na rua e fizeram suas vozes serem ouvidas.

\section{“Nossa luta começou, para parar não tem mais jeito... Leva eu, povo da rua"16}

Em 1989, houve uma grande mudança. Eleita, a prefeita Luíza Erundina assumiu a responsabilidade social com as pessoas da rua, o que nunca havia acontecido. Ela criou uma programação específica para a população de rua: um primeiro albergue ${ }^{17}$ embaixo do viaduto da rua Pedroso, casas

\footnotetext{
${ }^{15}$ Anos mais tarde, em 1995, o dia 7 de setembro passou a ser o dia do Grito dos Excluídos, quando um conjunto de manifestações populares, como caminhadas, romarias, debates e outros eventos, mobilizadas por grupos e organizações sociais, denunciam os mecanismos de exclusão e reivindicam justiça.

${ }^{16}$ Verso da composição "Oi, leva eu, povo da rua", cuja letra foi colocada na melodia de uma música popular brasileira, cantada por Nilo Amaro e seus Cantores de Ébano, "Leva eu, sodade", 1961.

${ }^{17}$ A reivindicação de albergues àquela época representava a única possibilidade de abrigamento para as pessoas que viviam na rua e fazia parte de um programa de transição para uma política de moradia permanente para a população da rua. Infelizmente, nos governos seguintes, os alber-
} 
de convivência (onde as pessoas da rua podiam passar o dia) nos bairros da Ponte Pequena e do Brás, a comunidade S. Martinho de Lima no bairro do Belém, um centro de comunicação e documentação, a cessão de área debaixo do viaduto da rua João Moura, no bairro de Pinheiros, para a cooperativa de catadores/as etc. As casas de convivência foram inspiradas e organizadas a partir do funcionamento do centro comunitário do Glicério.

As organizações que trabalhavam com a rua passaram a se reunir em fórum para discutir uma política de ação com a população de rua. Disso resultou o Primeiro Seminário Nacional da População de Rua, em 1995. E a partir dessas discussões entre a população de rua, educadores e o poder legislativo municipal, criou-se a Lei 12.316 de 16/04/1997, Lei de Atenção à População de Rua.

Aos poucos, o povo da rua foi se organizando. Costumava-se falar que o povo da rua também estava em movimento... Depois do Massacre da Sé ${ }^{18}$ de 19 de agosto de 2004, em um encontro de catadores/as na cidade de Belo Horizonte/MG (em um evento chamado Festival Lixo Cidadania), foi feita a solicitação ao então Ministro do Desenvolvimento Social, Patrus Ananias, para colocar na agenda federal a pauta da população em situação de rua. Nascia, oficialmente, o Movimento Nacional da População de Rua, em 2004.

A partir de então, iniciou-se o processo de construção de uma lei federal de política pública para a população em situação de rua, chegado a termo no Decreto Federal n. 7.053 de 23/12/2009. O processo de construção desse decreto aconteceu a partir de reuniões entre a população de rua, técnicos e profissionais da área social de diferentes cidades do Brasil, e significou um grande salto em relação à visão do poder público sobre as pessoas que vivem na rua: não se trata de uma lei de assistência, mas de reconhecimento do Direito. O cerne do decreto são os direitos humanos da população de rua à moradia, ao trabalho, à saúde, educação, lazer etc. E foram criados para sua implantação o comitê federal e comitês locais, no caso dos municípios que assumiram esse compromisso social. A coordenação geral ficou a cargo da Secretaria de Direitos Humanos, e não da Assistência Social. Ou seja, trata-se de uma política não de assistência, emergencial, e sim uma política de direitos, estruturante, perene.

O dia 19 de agosto, memorial do Massacre na Sé, foi assumido pelos grupos organizados da população de rua no Brasil como o Dia Nacional de Luta da População em Situação de Rua.

Oi, leva eu, povo da rua, que eu também quero ir,

povo da rua, que já chegou a missão,

vamos todos nos unir, leva eu, povo da rua. (bis)

- Trabalhamos todos juntos, povo da rua, verdadeiro mutirão, povo da rua.

gues tornaram-se um programa permanente.

${ }^{18}$ No dia 19 de agosto de 2004, houve um terrível massacre de pessoas que viviam na rua no centro da cidade de São Paulo, na Praça da Sé. 
Fé em Deus e pé na tábua, buscando a libertação. Leva eu, povo da rua.

- Neste tempo tão difícil, povo da rua, a cidade vai ouvir, povo da rua,

o grito dos oprimidos pra justiça construir. Leva eu, povo da rua.

- Somos o povo de Deus, povo da rua, nós também temos direito, povo da rua.

Nossa luta começou, pra parar não tem mais jeito. Leva eu, povo da rua.

\section{Da Sopa Comunitária à Associação Minha Rua, Minha Casa}

O encerramento da sopa comunitária, por volta do ano 1994, se deu porque a realidade havia se transformado e os objetivos iniciais já não respondiam às novas demandas da rua. A convivência já não era mais possível com as 600 pessoas que vinham para a sopa. Nessa época, recebemos a visita de um grupo de empresários do Pensamento Nacional das Bases Empresariais, trazido pela secretária da Assistência Social, para que eles pudessem conhecer as pessoas da rua e suas necessidades. O objetivo deles, inicialmente, era financiar uma distribuição diária de cinco mil pratos de sopa. Porém, ao perceberem a realidade e a capacidade de articulação das pessoas da rua, saíram impressionados e se formou um grupo de trabalho para refletir sobre o aproveitamento do espaço debaixo do viaduto. Depois de muita conversa, surgiu a ideia de haver um espaço onde as pessoas da rua pudessem exercitar outro tipo de relação, e onde tivessem também uma infraestrutura para o acolhimento (assim não mais precisaríamos buscar água no posto de gasolina, por exemplo): banheiros, cozinha, salas de reunião, biblioteca etc. Criou-se a Associação Minha Rua, Minha Casa (AMR$\mathrm{MC}$ ), debaixo do viaduto do Glicério, no mesmo lugar onde, anteriormente, acontecia a sopa.

Cada pessoa da rua que se comprometia tornava-se, agora, um/a associado/a, o que significava que eles/as iriam discutir a programação e o funcionamento da Associação. Um aspecto importante era a organização em equipes, por exemplo: cozinha, limpeza, cultura, rádio comunitária, jardinagem, ornamentação do viaduto, segurança, lugar para escrever cartas para as famílias, mesa de costura, artesanato, arte-terapia, grupo "Batuque da Rua" (que, anualmente, compunha um samba-enredo e, no Carnaval, desfilava no bairro). Cada equipe tinha um educador contratado que fazia a tarefa junto com as pessoas, por exemplo, lavar o banheiro. No convívio em cada equipe, acontecia o acompanhamento e realizavam-se os encaminhamentos para responder às necessidades trazidas pelo/a associado/a. Fazendo um processo pessoal, ele/ela se abria para o seu entorno e se preparava para acolher os novos companheiros da rua que sempre chegavam ao espaço de encontro. Dizíamos que, neste processo, as pessoas "olhavam para si, para o outro e para o mundo".

Também se desenvolveu um grupo de geração de renda, chamado "Caminhos Produtivos", por exemplo, de jardinagem em praças públicas e 
edifícios particulares, de alimentação (bolo, pão...) e de produtos de limpeza artesanais.

O espaço da AMRMC tornou-se também um lugar para a "iniciação à rua" para pessoas que não tinham uma vivência na rua. Vale lembrar que todas as atividades na Casa de Oração e na Associação Minha Rua, Minha Casa eram realizadas com as pessoas que viviam na rua, mas, com o tempo, muita gente - com ou sem experiência em paróquias, seminaristas, religiosas/os, estrangeiros residentes no Brasil ou pessoas que desejavam viver uma experiência eclesial diferenciada - se aproximou da comunidade do povo da rua. Assim, adotamos como critério para quem quisesse participar da comunidade, mas não conhecia a rua, que essa pessoa não poderia realizar nenhuma tarefa antes de vivenciar um processo de "iniciação à rua" (com duração indeterminada). A realidade da rua e a dinâmica interna da comunidade eram completamente diferentes da vida em paróquias. Era necessário mudar a mentalidade de "fazer tarefas" ou de ver o povo da rua como "pobres" que precisam de ajuda. Antes, tratava-se de aprender a ouvir o povo da rua e reconhecer sua autonomia.

\section{"Catador de Norte a Sul ... Nesta marcha sem parar, caminhar é resistir e se unir é reciclar"...19}

Da experiência no dia-a-dia da rua, fomos percebendo diferentes grupos que se juntavam por interesses comuns, por exemplo, catadores de papel, limpadores de carro, guardadores de carros em estacionamentos de rua. Um deles, o de catadores de papel, participava frequentemente de nossas atividades. Começamos a conversar sobre o trabalho deles e suas dificuldades. Todos carregavam o material coletado na cabeça. Por isso, decidimos fazer uma carrocinha. A partir daí, a cada dia, dois catadores fariam a coleta de material na rua e venderiam em um depósito. Retirariam 10\% do que ganhassem para fazer uma caixa comum. Então, fizemos mais uma carrocinha, outra e mais outra... o grupo crescia.

Mas a luta não foi fácil. Em 1985, a prefeitura perseguia os/as catadores/as e recolhia as carrocinhas. Depois de muito debate sobre o direito ao trabalho dos/as catadores/as na cidade, com a ajuda de uma advogada, criou-se a primeira Associação de Catadores de Papel do Brasil, em 1985. Um grupinho mais organizado continuou seu trabalho de coleta seletiva e comercialização e, novamente, depois de muito estudo, criou-se, em 1989, a primeira cooperativa do Brasil, a Coopamare (Cooperativa de Catadores de Papel, Papelão e Materiais Reaproveitáveis), que seria referência para a formação de tantas outras cooperativas. Desse trabalho, iniciou-se a articulação com outras cidades, culminando, em 2001, no Primeiro Congresso Nacional de Catadores/as de Materiais Recicláveis, em Brasília, capital

${ }^{19}$ Verso do Hino aos Catadores, composto por Dimir Vianna. 
do Brasil, onde se deu a criação do Movimento Nacional de Catadores de Materiais Recicláveis. Por ocasião do Congresso, organizou-se uma Marcha Nacional dos Catadores juntamente com a população de rua de diferentes estados brasileiros. No ano seguinte, em 2002, realizou-se o Primeiro Congresso Latino-Americano de Catadores/as de Materiais Recicláveis, na cidade de Caxias do Sul/RS, Brasil.

Ao longo desse processo de resistência e conquista de políticas públicas, os/as catadores/as assumiram um lugar fundamental na sociedade brasileira, obtendo apoio do governo federal para uma capacitação nacional e participando da discussão da Política Nacional de Resíduos Sólidos, que resultou na Lei n. 12.305/10. E não parou ali. Hoje, os/as catadores/as, além da América Latina e Caribe, percorrem países como Índia, Angola, França, entre outros, compartilhando experiências de trabalho e organização. E, embora os desafios e as perseguições continuem, assim cantam no Hino aos Catadores/as:

- Quem sabe andar nessa rua vai em frente, pois atrás é que vem gente, diz o dito popular. E quem caminha na linha da esperança arrasta o pé, balança a trança, na dança de se chegar.

Há quem diga olê, olê! Olê, olá! Catador de Norte a Sul, e de acolá!

Nessa marcha sem parar, caminhar é resistir e se unir é reciclar! (bis)

- Ninguém segura essa gente que trabalha, que grita e fala querendo anunciar que é possível a luz de um novo dia em que a nossa alegria possa se concretizar! - Povo da rua não é do mundo da lua, é a vontade nua e crua, é o desejo de um lar, que assegure vida e dignidade, rumo de prosperidade e o direito de sonhar! (Dimir Vianna)

\section{A Casa Acolhe a Rua}

No ano de 2014, fechamos a AMRMC. O poder público exigia que o recurso financeiro fosse destinado, principalmente, à alimentação. Entendíamos que era necessário mais do que isso, e já havia diversos serviços na cidade que atendiam a esse propósito. Ficou inviável conciliar as exigências da prefeitura e a metodologia por meio da qual buscávamos o protagonismo da população de rua. Além disso, a prefeitura investiu em uma série de programas com outras entidades que afetava diretamente a cultura da rua, retomando a mentalidade do assistencialismo.

Mesmo após o fechamento do programa da AMRMC, permanecemos debaixo do viaduto e fizemos uma capacitação de um ano e meio, com o propósito de as pessoas fazerem um caminho, passo a passo, para aprender a buscar o seu direito junto aos órgãos públicos e à sociedade - chamou-se "Direitos Humanos no Viaduto".

Juntamente com o desemprego, diversas causas levam a viver na rua, num processo de perdas sucessivas: sem trabalho, a impossibilidade do autossustento e de moradia, conflitos familiares, álcool, drogas, sofrimento 
mental, perda dos documentos na rua, às vezes delitos, furtos, crimes, prisão etc. Criar um novo caminho, com o medo de um "segundo fracasso", é desestabilizador. Não basta "dar uma casa". É preciso acompanhar o processo de saída da rua e a reorganização da vida. Há vários programas na cidade, porém com finalidade em si mesmos - sem perspectiva e metodologia de transição para a saída da rua.

Hoje, nossa prioridade é a moradia. É verdade que, desde os anos 80, já acompanhávamos as ocupações de casas abandonadas utilizadas pelas pessoas da rua e ajudávamos na compra de barracos na periferia da cidade. Mas, atualmente, na casa onde funcionou o centro comunitário nas décadas de 1980 e 1990, há um programa de moradias provisórias coletivas ("repúblicas"), chamado A Casa Acolhe a Rua, que representa uma possibilidade de "treinamento" para sair da rua e assumir uma moradia permanente.

A Casa Acolhe a Rua compreende seis pequenas casas antigas, com capacidade para 8 a 10 pessoas em cada uma. Trata-se de um programa subsidiado pela prefeitura, onde os moradores tem participação ativa nas decisões da casa e nos movimentos sociais de moradias populares. A participação nas atividades de manutenção, organização e discussão de moradia propicia o estímulo à reconstrução de vínculos pessoais, comunitários e de trabalho. Nos últimos anos, com o crescente número de imigrantes, muitos têm procurado as repúblicas, provenientes de diversos países: Marrocos, Congo, Senegal, Costa do Marfim, Angola, Nigéria, Guiné Bissau, Chade, Cabo Verde, Cuba, Haiti, Venezuela, Bolívia, Colômbia, entre outros. A convivência possibilita a experiência com a diversidade cultural, com opiniões diferentes e novas maneiras de lidar como os conflitos que aparecem.

Nos anos de 2019 e 2020, estamos fazendo uma capacitação nas repúblicas para os moradores e outras pessoas em situação de rua intitulada "Moradia Primeiro, Direito da Rua". A capacitação tem como objetivo formar agentes defensores do direito humano à moradia digna e produzir conhecimento sistematizado que contribua na construção de políticas públicas de habitação para as pessoas em situação de rua.

\section{Somos um povo que quer viver!}

Todo esse trabalho tem atingido seu objetivo inicial de construção de políticas públicas para as pessoas em situação de rua. Recentemente, houve a sua inclusão no Plano Municipal de Habitação da cidade de São Paulo e a aprovação do Plano Municipal de Política Pública para a População em Situação de Rua (PL 000145/2018). Em fevereiro de 2019, foi inaugurada pelo prefeito da cidade um projeto-piloto de locação social para a população em situação de rua: um edifício com 34 unidades, para 87 pessoas - famílias com crianças, homens e mulheres sozinhos, LGBTs e pessoas com sofrimento mental. Os critérios para a distribuição dos apartamentos foram 
feitos a partir de um grupo formado pelo comitê da população de rua. Os desafios continuam, mas também permanecem a esperança e a coragem de seguir em frente, juntos/as.

Relendo a história, vemos como foi importante sempre escutar e dialogar com a realidade - rever, transformar, mudar; acreditar no potencial das pessoas, valorizar as atividades que exerciam para sobreviver, respeitar o tempo de cada uma na reorganização de suas vidas; refletir e agir coletivamente; criar espaços de resistência através do teatro, da música, da dança, da poesia; permanecer no compromisso cotidiano ao longo desses quase 70 anos... O trabalho político-social, neste caso, se deu (e se dá) a partir da espiritualidade da comunidade, pautada em uma vida de oração pessoal e comunitária, na leitura bíblica, na partilha do pão e nas amizades construídas em meio à dor e à alegria. Afinal, podemos dizer junto com o povo da rua que "Entre a vida e a morte, a vida é mais forte"!

Regina María Manoel

regina.mar@globo.com

Cecilia Toseli

cecilia.toseli@gmail.com 